\title{
Surgery for congenital mitral valve disease in the first year of life
}

Between 1980 and 1993, 20 patients less than 1 year of age underwent operations for congenital mitral valve disease. Ten patients had congenital mitral incompetence and 10 had congenital mitral stenosis. Mean age was $6.6 \pm 3.4$ months and mean weight was $5.6 \pm 1.5 \mathrm{~kg}$. Atrioventricular canal defects, univentricular heart, class III/IV hypoplastic left heart syndrome, discordant atrioventricular and ventriculoarterial connections, and acquired mitral valve disease were excluded. Indications for operation were intractable heart failure or severe pulmonary hypertension, or both. Associated lesions, present in $90 \%$ of the patients, had been corrected by a previous operation in seven. In congenital mitral incompetence there was normal leaflet motion $(n=3)$, leaflet prolapse $(n=2)$, and restricted leaflet motion $(n=5)$. In congenital mitral stenosis anatomic abnormalities were parachute mitral valve $(n=$ 4), typical mitral stenosis $(n=3)$, hammock mitral valve $(n=2)$, and supramitral ring $(n=1)$. Mitral valve repair was initially performed in 19 patients and valve replacement in one with hammock valve. Concurrent repair of associated lesions was performed in 12 patients. The operative mortality rate was zero. There were six early reoperations in five patients for mitral valve replacement $(n=4)$, a second repair $(n=1)$, and prosthetic valve thrombectomy $(n=1)$. One late death occurred 9 months after valve replacement. Late reoperations for mitral valve replacement $(n=2)$, aortic valve replacement $(n=1)$, mitral valve repair $(n=2)$, subaortic stenosis resection $(n=1)$, and second mitral valve replacement $(n=1)$ were performed in five patients. Actuarial freedom from reoperation is $58.0 \% \pm 11.3 \%(70 \%$ confidence limits $46.9 \%$ to $68.9 \%$ ) at 7 years. After a mean follow-up of $67.6 \pm \mathbf{4 2 . 8}$ months, $94 \%$ of living patients are in New York Heart Association class I. Doppler echocardiographic studies among the 13 patients with a native mitral valve show mitral incompetence of greater than moderate degree in one patient and no significant residual mitral stenosis. Overall, six patients have mitral prosthetic valves with a mean transprosthetic gradient of $6.2 \pm 3.7 \mathrm{~mm} \mathrm{Hg}$. These results show that surgical treatment for congenital mitral valve disease in the first year of life can be performed with low mortality. Valve repair is a realistic goal in about $70 \%$ of patients and possibly more with increased experience. Reoperation rate is still high and is related to complexity of mitral lesions and associated anomalies, but late functional results are encouraging. (J THORAC CARDIOVASC SURG 1995;109:164-76)

Miguel Sousa Uva, MD (by invitation), Lorenzo Galletti, MD (by invitation), François Lacour Gayet, MD (by invitation), Dominique Piot, MD (by invitation),

A. Serraf, MD (by invitation), Jacqueline Bruniaux, MD (by invitation), Juan Comas, MD

(by invitation), R. Roussin, MD (by invitation), A. Touchot, MD (by invitation),

Jean Paul Binet, MD, and Claude Planché, MD, Paris, France

From The Department of Pediatric Cardiac Surgery, Marie Lannelongue Hospital, Paris, France.

Read at the Seventy-fourth Annual Meeting of The American Association for Thoracic Surgery, New York, N.Y., April 24-27, 1994.

Address for reprints: Claude Planché, MD, Hôpital Marie Lannelongue, Departement de Chirurgie Cardiaque Pédiatrique, 133, Avenue de la Résistance, Plessis Robinson 92350, France.

Copyright $(\mathcal{C} 1995$ by Mosby-Year Book, Inc.

$0022-5223 / 95 \$ 3.00+0 \quad \mathbf{1 2 / 6 / 6 0 1 3 8}$
$\mathrm{C}$ opmental malformation characterized by a wide spectrum of morphologic abnormalities and a high incidence of associated cardiac anomalies. ${ }^{1-5}$ Several authors have made important contributions leading to significant advances in pathologic, clinical, and therapeutic aspects of congenital mitral valve disease, but few have focused on the specific issue of very early presentation. ${ }^{6-9}$ Congenital mitral valve 
Table I. Preoperative clinical data

\begin{tabular}{|c|c|c|c|c|c|}
\hline $\begin{array}{l}\text { Patient } \\
\text { No. }\end{array}$ & $\begin{array}{l}\text { Age } \\
\text { (mo) }\end{array}$ & $\begin{array}{l}\text { Weight } \\
(\mathrm{kg})\end{array}$ & $\begin{array}{l}\text { Type of } M V \\
\text { dysfunction }\end{array}$ & $\begin{array}{l}\text { Associated } \\
\text { anomalies }\end{array}$ & Previous operations \\
\hline 1 & 8 & 6.9 & MI & DORV & - \\
\hline 2 & 7 & 6.5 & MI & Coarctation & Coarctectomy \\
\hline 3 & 12 & 6.8 & MI & ASD & - \\
\hline 4 & 6 & 6 & MI & - & - \\
\hline 5 & 6 & 4.6 & MI & PDA & - \\
\hline 6 & 8 & 5.4 & MI & AS & Aortic commissurotomy \\
\hline 7 & 5.5 & 3.3 & MI & PDA & - \\
\hline 8 & 9 & 5.6 & MI & Coarctation & Coarctectomy \\
\hline 9 & 10 & 7.1 & MI & VSD & - \\
\hline 10 & 2 & 4.1 & MI & - & - \\
\hline 11 & 2.5 & 4.2 & MS & VSD (multiple) & - \\
\hline 12 & 12 & 6.8 & MS & AS & - \\
\hline 13 & 2 & 3.2 & MS & AS & Closed aortic valvulotomy \\
\hline 14 & 6 & 6.5 & MS & VSD & - \\
\hline 15 & 2.5 & 5.1 & MS & VSD & - \\
\hline 16 & 7 & 6.3 & MS & SAS, coarctation & Coarctectomy \\
\hline 17 & 2 & 3.9 & MS & ASD & - \\
\hline 18 & 12 & 8.8 & MS & VSD & $\begin{array}{l}\text { VSD closure } \\
\text { PDA division }\end{array}$ \\
\hline 19 & 8.5 & 6 & MS & SAS, coarctation & Coarctectomy \\
\hline 20 & 3 & 4.5 & MS & DORV, PS & - \\
\hline
\end{tabular}

$M V$, Mitral valve; $M I$, mitral incompetence; $M S$, mitral stenosis; $D O R V$, double-outlet right ventricle; $A S D$, atrial septal defect; $P D A$, patent ductus; $A S$, aortic stenosis; VSD, ventricular septal defect; $S A S$, subaortic stenosis; $P S$, pulmonary stenosis.

disease in infancy reflects severeness of the mitral valve malformations or associated conditions. Natural history in these cases is particularly dismal, with death occurring in the first months of life. ${ }^{10,11}$ In view of its poor results, surgical treatment for congenital mitral valve disease is always delayed until severe symptoms develop with medical treatment but may occasionally be unavoidable. Despite advances in the treatment of complex congenital heart defects in very small infants, congenital mitral incompetence (MI) or stenosis (MS) sufficiently severe to require an operation during the first year of life is still a therapeutic challenge. Mitral valve repair has been advocated and deemed possible in the majority of these patients. ${ }^{6,12}$ However, the number of surgically treated infants with congenital mitral valve disease is small in any individual institutional experience.

In view of limited information on selection of procedures and results in infants operated on for congenital mitral valve disease, we have reviewed a 13-year experience at our institution.

\section{Patients and methods}

Patients. From January 1980 through December 1993, we have retrospectively reviewed the records of all patients less than 1 year of age who were operated on at Marie Lannelongue Hospital for congenital MI or MS, whether isolated or associated with other congenital malformations.

Left atrioventricular valve anomalies associated with atrioventricular canal defects, class III/IV hypoplastic left heart syndrome, atrioventricular discordance, complete transposition, straddling mitral valve, univentricular atrioventricular connections, and acquired mitral valve disease were excluded from this study. Also excluded was MI resulting from anomalous origin of the left coronary artery. The patients included 15 boys and five girls with a mean age of $6.6 \pm 3.4$ months ( 2 to 12 months) and a mean weight of $5.6 \pm 1.5 \mathrm{~kg}$. Ten patients had predominant MI (mean age 7.4 \pm 2.7 months) and 10 had predominant MS (mean age $5.8 \pm 3.9$ months).

Preoperative symptoms consisted of congestive heart failure, poor growth, and pulmonary hypertension. Operation was indicated in the presence of systemic pulmonary hypertension or repeated episodes of poorly tolerated cardiac failure unresponsive to medical treatment. Eleven patients were in New York Heart Association (NYHA) functional class IV (severe heart failure with tachypnea, tachycardia, and hepatomegaly) and nine patients were in class III (frequent episodes of pulmonary infection or heart failure with underdevelopment). Three patients with MI and one with MS were intubated and their lungs were mechanically ventilated before the operation. The operation was delayed until after 6 months if possible. The interval between the onset of symptoms and time of operation ranged between 0.5 and 5 months (mean 1.8 months).

Seven patients had undergone previous operations. Four had coarctation repair, two had aortic commissurot- 
Table II. Preoperative Doppler echocardiographic and catheterization data in patients with MI

\begin{tabular}{|c|c|c|c|c|c|c|c|c|c|}
\hline \multirow[b]{2}{*}{$\begin{array}{l}\text { Patient } \\
\text { No. }\end{array}$} & \multicolumn{6}{|c|}{ Echocardiographic data } & \multicolumn{3}{|c|}{ Catheterization data } \\
\hline & $\begin{array}{c}M I \\
\text { degree } \\
(1-4)\end{array}$ & $\begin{array}{c}\text { MI } \\
\text { mechanism* }\end{array}$ & $\begin{array}{c}\text { Annular } \\
\text { diameter } \\
(\mathrm{mm})\end{array}$ & $\begin{array}{c}\angle V E D D \\
(\mathrm{~mm})\end{array}$ & $\begin{array}{c}\angle V E S D \\
(\mathrm{~mm})\end{array}$ & $\begin{array}{c}L A \\
\operatorname{diam} \\
(\mathrm{mm})\end{array}$ & $\begin{array}{c}L A P \\
(m m H g)\end{array}$ & $\begin{array}{c}P A P \\
\text { syst } \\
(m m ~ H g)\end{array}$ & $\begin{array}{c}P A P \\
\text { mean } \\
(m m H g)\end{array}$ \\
\hline 1 & 3 & II (AL) & 25 . & 35 & 17.5 & 30 & 15 & 48 & 30 \\
\hline 2 & 3 & $\mathrm{II}(\mathrm{AL})$ & 17 & 41 & 17 & 35 & - & - & - \\
\hline 3 & 4 & III & 25 & 42 & 25 & 50 & 15 & 45 & 29 \\
\hline 4 & 3 & $\mathrm{I}$ & 20 & 38 & 27 & 55 & 16 & 40 & 22 \\
\hline 5 & 3 & I & 23 & 33 & 21 & 30 & 24 & 96 & 75 \\
\hline 6 & 3 & I & - & - & - & - & - & - & - \\
\hline 7 & 4 & III & 21 & 47 & 30 & 30 & 34 & 85 & 72 \\
\hline 8 & 4 & III & 20 & 26 & 13 & 33 & 16 & 52 & 45 \\
\hline 9 & 3 & III & 24 & 32 & 15 & 50 & 14 & 91 & 62 \\
\hline 10 & 4 & III & 18 & 32 & 19 & 30 & 6 & - & 30 \\
\hline
\end{tabular}

$M I$, Mitral incompetence; $L V E D D$, left ventricular end-diastolic dimension; $L V E S D$, left ventricular end-systolic dimension; $L A$, left atrium; $L A P$, left atrial pressure; $P A P$, pulmonary artery pressure; $A L$, anterior leaflet.

${ }^{*}$ Carpentier's classification.

omy, and one had VSD closure. Associated anomalies were present in all but two patients and are listed in Table I. Shone syndrome was present in three patients.

Two-dimensional echocardiography and Doppler examination were performed before the operation. Mitral valve structure, papillary muscle architecture, and functional analysis of leaflet motion were examined from multiple views. Mitral anulus diameter at the hinge points of the leaflets was measured from the apical four-chamber view. Maximum instantaneous and mean gradients across the mitral valve were calculated by the modified Bernoulli equation. The degree of MI was estimated by color Doppler echocardiography. Cardiac catheterization was performed in the majority of patients. Mean systolic pulmonary artery pressure was $63.9 \pm 20.3 \mathrm{~mm} \mathrm{Hg}$. Results of preoperative investigations are summarized in Tables II and III.

Congenital MI. MI was grade $3 / 4$ or $4 / 4$ in all patients. Isolated annular dilatation was the cause of $\mathrm{MI}$ in three cases, leaflet prolpase in two, and restricted leaflet motion in five. Mean mitral anulus diameter was $21.4 \mathrm{~mm}$ (range 7 to $15 \mathrm{~mm}, Z$ value $>+5$ in all patients). The left ventricular mean diameter was $36.2 \mathrm{~mm}$ (range 26 to 47 $\mathrm{mm}$ ), two standard deviations above normal values. ${ }^{13}$

Congenital MS. The inflow obstruction to the left ventricle was at multiple levels in more than half of the patients. Mean mitral anulus diameter was $11.7 \mathrm{~mm}$ (range 7 to $15 \mathrm{~mm}$ ), with a $Z$ value ranging from -1 to -3 . Two patients with MS also had mild MI. Figs. 1 and 2 show two-dimensional echocardiographic views of a parachute mitral valve and a hammock mitral valve (patients 18 and 19).

During this study, congenital mitral valve disease was diagnosed in 24 additional infants ( $16 \mathrm{MS}, 8 \mathrm{MI}$ ), four of whom underwent operation after 1 year of age and therefore are not included in this series.

Operative findings and surgical technique. All patients underwent operation by means of a median sternotomy with the aid of hypothermic continuous cardiopulmonary bypass. In two cases of congenital MS circulatory arrest was used. After aortic crossclamping and infusion of cardioplegic solution the mitral valve was exposed through the interatrial groove in 15 cases and the interatrial septum in four. In one case an extended vertical transatrial septal approach was used. All mitral valve apparatus components were analyzed with the objective of establishing the mechanisms of MI or MS. Echocardiographic data and intraoperative findings correlated well.

Congenital MI. Annular dilatation was a constant feature in this series. Systolic restriction of the posterior leaflet caused by short chordae associated with variable degrees of leaflet hypoplasia was the most frequent anomaly responsible for MI. Treatment consisted of annuloplasty at either the commissural level or posterior leaflet level by standardized techniques. ${ }^{14-16}$ Chordal mobilization was performed by resection of intermediary chordae or incision of papillary muscle. Prosthetic ring annuloplasty was not used. Before closure of the atrium the mitral valve was tested for regurgitation with saline solution. A reparative procedure was performed in all patients with MI.

Congenital MS. Parachute mitral valve was the most frequent lesion found, followed by commissural fusion, short chordae, obliterated interchordal spaces, and diminished interpapillary distance (typical mitral stenosis of Van Praagh or commissure-papillary muscle fusion of Carpentier's classification). ${ }^{3,6}$ Surgical procedures consisted of resection of supravalvular membrane, commissurotomy, papillary muscle vertical incision, chordal fenestration, muscular resection, and instrumental annular dilation. One patient with the so-called hammock mitral valve underwent valve replacement with a $19 \mathrm{~mm}$ St. Jude Medical valve (St. Jude Medical, Inc., St. Paul, Minn.). The nine other patients initially had a conservative procedure. Intraoperative findings and surgical procedures are summarized in Tables IV and V. Mean crossclamp time and cardiopulmonary bypass time were 46 and 86 minutes, respectively.

Follow-up. Postoperative inquiry was performed between January and March 1994 through letters or telephone calls to the referring pediatric cardiologist. Patients were regularly followed up clinically and by Doppler 


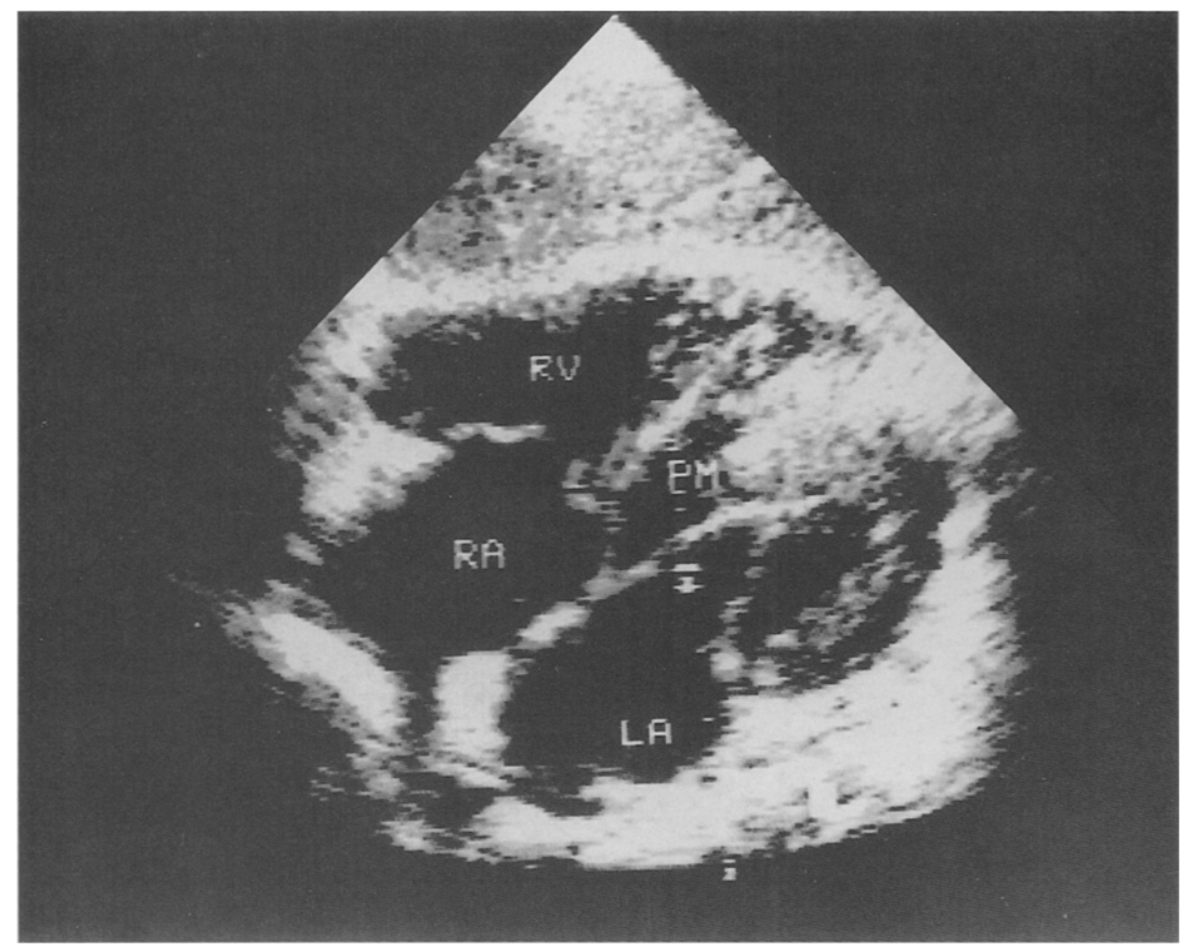

Fig. 1. Subcostal four-chamber two-dimensional echocardiographic view of a parachute mitral valve with direct attachment of the two leaflets into a single papillary muscle (patient 18). $L A$, Left atrium; $R V$, right ventricle; $R A$, right atrium; $P M$, papillary muscle.

Table III. Preoperative Doppler echocardiographic and catheterization data in patients with MS

\begin{tabular}{|c|c|c|c|c|c|c|c|}
\hline \multirow[b]{2}{*}{$\begin{array}{c}\text { Patient } \\
\text { No. }\end{array}$} & \multicolumn{4}{|c|}{ Echocardiographic data } & \multicolumn{3}{|c|}{ Catheterization data } \\
\hline & $\begin{array}{c}\text { Level of } \\
\text { obstruction }\end{array}$ & MS mechanism & $\begin{array}{c}\text { Mean } \\
\text { transmitral } \\
\text { gradient } \\
(\mathrm{mm} \mathrm{Hg})\end{array}$ & $\begin{array}{c}\text { Anulus } \\
\text { diameter } \\
(m m)\end{array}$ & $\begin{array}{c}L A P \\
(m m H g)\end{array}$ & $\begin{array}{c}P A P \\
\text { syst } \\
(m m H g)\end{array}$ & $\begin{array}{c}P A P \\
\text { mean } \\
(m m H g)\end{array}$ \\
\hline 11 & V, SubV & Short chordae, near fused PM & - & - & - & 62 & 42 \\
\hline 12 & V, SubV & Hammock & - & 15 & 18 & 46 & 26 \\
\hline 13 & V, SubV & Short chordae, hypertrophic PM & - & - & 21 & 58 & 36 \\
\hline 14 & SupraV & SMR, short chordae & 13 & 12 & 19 & 96 & 60 \\
\hline 15 & $\mathrm{~V}$, SubV & Parachute & 10 & 13 & 16 & 75 & 56 \\
\hline 16 & SupraV, V, SubV & Parachute, SMR (Shone) & 10 & 7 & 18 & 55 & 34 \\
\hline 17 & V, SubV & Short chordae, near fused PM & 21 & 9 & - & - & - \\
\hline 18 & V, SubV & Parachute & 15 & 13 & 15 & 60 & 45 \\
\hline 19 & V, SubV & Hammock, SMR, annular hypoplasia & 9 & 13 & - & - & - \\
\hline 20 & V, SubV & Parachute, SMR & 12 & 12 & - & 75 & 48 \\
\hline
\end{tabular}

$\overline{M S}$, Mitral stenosis; $L A P$, left atrial pressure; $P A P$, pulmonary artery pressure; $V$, valvular; $S u b V$, subvalvular; SupraV, supravalvular; $P M$, papillary muscle; SMR, supramitral ring.

echocardiographic examination. Two patients from overseas could not be traced after being discharged alive after valve repair for MI, one in 1987 and one in 1988 (2 and 3 months after repair). Mean follow-up time for survivors is $67.6 \pm 42.8$ months ( 5 to 134 months).

Data analysis. Whenever deemed necessary, dimensions were transformed to $Z$ values. Survival and freedom from other time-related events were computed with the Kaplan-Meier life table method.

\section{Results}

Early results. No early deaths occurred in this series. 


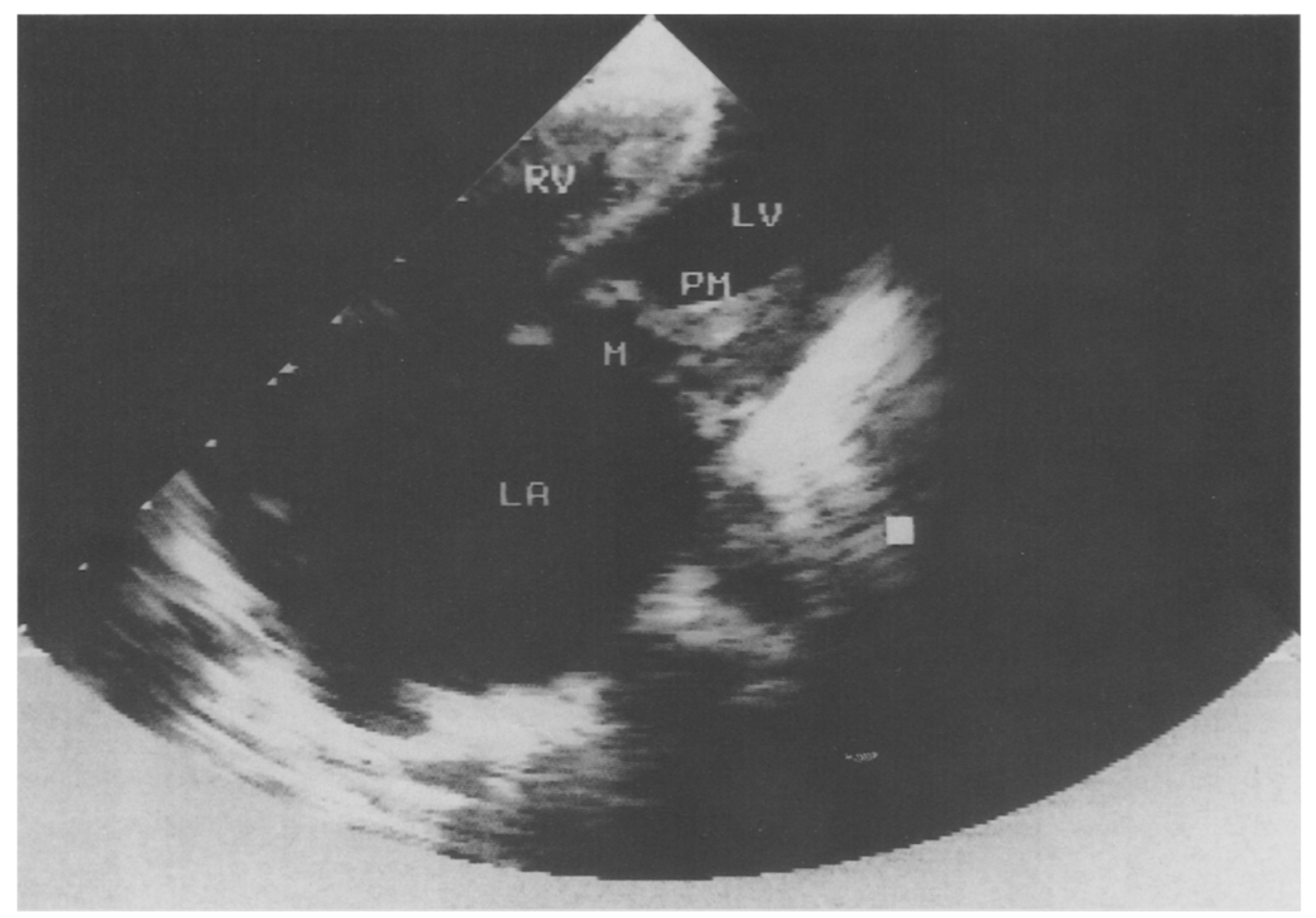

Fig. 2. Four-chamber apical two-dimensional echocardiographic view of a hammock mitral valve (patient 19). Note the direct leaflet attachment to a posterior papillary muscle with absent chordae. $L A$, Left atrium; $L V$, left ventricle; $M$, mitral valve; $P M$, papillary muscle; $R V$, right ventricle.

Congenital MI. Seven patients had no or minimal MI on Doppler echocardiographic studies before discharge from the hospital. Three patients had moderate-to-severe residual MI and underwent reoperation between 1 and 4 weeks after the first operation. Two underwent mitral valve replacement with a $19 \mathrm{~mm}$ St. Jude Medical valve and one had a second valve repair (patients 2, 3, and 10).

Congenital MS. Among the nine patients who initially had a conservative procedure, five had a good or satisfactory initial result, with clinical improvement, diminished transmitral gradient, and no significant MI. Two patients had residual MS. One patient was discharged (patient 18) although she had some degree of cardiac failure. One patient with parachute mitral valve and double-outlet right ventricle underwent valve replacement with a $17 \mathrm{~mm}$ Björk-Shiley prosthesis (Shiley, Inc., Irvine, Calif.) placed in a supraannular position 7 days after attempted repair (patient 20). Two patients had residual MI. One was discharged and one patient, with parachute mitral valve, required mitral valve replacement at 1 month with a $17 \mathrm{~mm}$ Björk-Shiley valve for persisting residual MI (patient 15).
Morbidity. For the majority of patients the postoperative course was simple. Mean intubation time and intensive care unit stay were $2.2 \pm 1.7$ and $4.7 \pm$ 3.2 days, respectively, excluding one patient with double-outlet right ventricle and parachute mitral valve who had a complicated course. This patient required a second reoperation for early valve thrombosis, then had mediastinitis, but finally recovered.

\section{Late results}

Congenital MI. No late deaths occurred in this group. One patient required mitral valve replacement with a $16 \mathrm{~mm}$ CarboMedics valve (CarboMedics, Inc., Austin, Tex.) 3 months after two unsuccessful attempts to repair an MI resulting from direct leaflet-papillary muscle attachment (patient 10). No other late reoperations were performed. Overall, three patients have had a mitral valve replacement and seven a valve repair. At latest follow-up, all patients are in NYHA class I, in sinus rhythm, with normal growth, and receive no medications other than oral anticoagulants (warfarin sodium) for those with prosthetic valves. Doppler echocardiographic studies at most recent follow-up of patients who had a valve repair showed moderate MI in three patients 
Table IV. Surgical findings and operative techniques in patients with MI

\begin{tabular}{|c|c|c|c|c|c|}
\hline $\begin{array}{l}\text { Patient } \\
\text { No. }\end{array}$ & $\begin{array}{l}\text { Age } \\
(m o)\end{array}$ & Surgical findings & Mitral valve procedure & $\begin{array}{l}\text { Concomitant } \\
\text { procedure }\end{array}$ & Early outcome \\
\hline 1 & 8 & $\begin{array}{l}\text { Papillary muscle elonga- } \\
\text { tion/malposition, AML } \\
\text { prolapse }\end{array}$ & Commissural annuloplasty & $\begin{array}{l}\text { VSD enlargement, } \\
\text { DORV repair }\end{array}$ & Good, minimal MI \\
\hline 2 & 7 & $\begin{array}{l}\text { Absent chordae, AML pro- } \\
\text { lapse, annular dilatation }\end{array}$ & Commissural annuloplasty & - & $\begin{array}{l}\text { Residual MI, MVR } \\
\quad(19 \mathrm{~mm})\end{array}$ \\
\hline 3 & 12 & $\begin{array}{l}\text { PML indentation, short } \\
\text { chordae, annular dilata- } \\
\text { tion }\end{array}$ & $\begin{array}{l}\text { Indentation closure, section } \\
\text { of chordae, commissural } \\
\text { annuloplasty }\end{array}$ & ASD closure & $\begin{array}{l}\text { Residual MI, MVR } \\
\quad(19 \mathrm{~mm})\end{array}$ \\
\hline 4 & 6 & Isolated annular dilatation & Posterior annuloplasty & - & Good, minimal MI \\
\hline 5 & 6 & Isolated annular dilatation & Commissural annuloplasty & Ductus division & Good, minimal MI \\
\hline 6 & 8 & Isolated annular dilatation & Posterior annuloplasty & - & Good, minimal MI \\
\hline 7 & 5.5 & $\begin{array}{l}\text { PML hypoplasia/retraction, } \\
\text { annular dilatation }\end{array}$ & Commissural annuloplasty & Ductus division & Good, minimal MI \\
\hline 8 & 9 & $\begin{array}{l}\text { PML hypoplasia/retraction, } \\
\text { AML indentation, annu- } \\
\text { lar dilatation }\end{array}$ & $\begin{array}{l}\text { Leaflet mobilization, inden- } \\
\text { tation closure, posterior } \\
\text { annuloplasty }\end{array}$ & 一 & Good, no MI \\
\hline 9 & 10 & $\begin{array}{l}\text { PML retraction, annular } \\
\text { dilatation }\end{array}$ & $\begin{array}{l}\text { Leaflet mobilization, com- } \\
\text { missural annuloplasty }\end{array}$ & VSD closure & Good, minimal MI \\
\hline 10 & 2 & $\begin{array}{l}\text { Short chordae to AML } \\
\text { and PML, annular dila- } \\
\text { tation }\end{array}$ & $\begin{array}{l}\text { Papillary muscle incision, } \\
\text { commissural annulo- } \\
\text { plasty }\end{array}$ & - & Residual MI, repair \\
\hline
\end{tabular}

$M I$, Mitral incompetence; $A M L$, anterior mitral leaflet; $P M L$, posterior mitral leaflet; $V S D$, ventricular septal defect; $A S D$, atrial septal defect; $M V R$, mitral valve replacement.

Table V. Surgical findings and operative techniques in patients with MS

\begin{tabular}{|c|c|c|c|c|c|}
\hline $\begin{array}{l}\text { Patient } \\
\text { No. }\end{array}$ & $\begin{array}{l}\text { Age } \\
(\mathrm{mo})\end{array}$ & Surgical findings & Mitral valve procedure & $\begin{array}{l}\text { Concomitant } \\
\text { procedure }\end{array}$ & Early outcome \\
\hline 11 & 2.5 & Typical MS & Commissurotomy & VSD closure & Good \\
\hline 12 & 12 & Hammock & MVR (19 mm) & $\begin{array}{l}\text { Aortic commissur- } \\
\text { otomy }\end{array}$ & Good \\
\hline 13 & 2 & $\begin{array}{l}\text { Typical MS, fibro- } \\
\text { elastosis }\end{array}$ & Commissurotomy, PM splitting & $\begin{array}{l}\text { Aortic commissur- } \\
\text { otomy }\end{array}$ & Good \\
\hline 14 & 6 & SMR & Ring resection & VSD closure & Good \\
\hline 15 & 2.5 & Parachute & $\begin{array}{l}\text { Chordal fenestration, PM } \\
\text { splitting }\end{array}$ & VSD closure & $\begin{array}{l}\text { Severe MI, MVR } \\
\quad(17 \mathrm{~mm})\end{array}$ \\
\hline 16 & 7 & $\begin{array}{l}\text { Parachute, SMR, } \\
\text { fibroelastosis }\end{array}$ & Ring resection & Subaortic resection & Good \\
\hline 17 & 2 & Typical MS & Commissurotomy, PM splitting & - & Moderate MI \\
\hline 18 & 12 & Parachute & Commissurotomy, PM splitting & - & Residual MS \\
\hline 19 & 8.5 & $\begin{array}{l}\text { Hammock, SMR, } \\
\text { small mitral anulus }\end{array}$ & $\begin{array}{l}\text { Commissurotomy, ring and } \\
\text { muscular resection }\end{array}$ & - & Good \\
\hline 20 & 3 & Parachute, SMR & $\begin{array}{l}\text { Commissurotomy, ring resec- } \\
\text { tion, PM splitting }\end{array}$ & DORV repair & $\begin{array}{l}\text { Residual MS, } \\
\text { MVR }(17 \mathrm{~mm})\end{array}$ \\
\hline
\end{tabular}

$M S$, Mitral stenosis; SMR, supramitral ring; $M V R$, mitral valve replacement; $P M$, papillary muscle; $V S D$, ventricular septal defect; $D O R V$, double-outlet right ventricle; $M I$, mitral incompetence.

and mild MI in two patients. Two patients whose mitral valve had been replaced with a $19 \mathrm{~mm}$ St. Jude Medical valve 6 and 7 years previously have moderate transprosthetic gradients (Table VI). Freedom from reoperation at 7 years is $61.2 \%(70 \%$ CL* $45.6 \%$ to $76.9 \%$ ) (Fig. 3).

$* \mathrm{CL}=$ Confidence limits.
Congenital MS. Four patients underwent late reoperation. Indication, type of operation, and interval from the first intervention are summarized in Table VII. One patient outgrew his prosthetic valve and underwent a second mitral valve replacement (with a prosthesis two sizes larger) 8 years after the initial procedure (patient 12). Aortic valve replacement and mitral valve repair for aortic stenosis and 
Table VI. Follow-up of patients with MI

\begin{tabular}{|c|c|c|c|c|c|c|c|}
\hline $\begin{array}{l}\text { Patient } \\
\text { No. }\end{array}$ & $\begin{array}{c}\text { Late } \\
\text { reoperations }\end{array}$ & $\begin{array}{l}\text { Interval } \\
\text { from first } \\
\text { operation }\end{array}$ & $\begin{array}{c}\text { NYILA } \\
\text { class }\end{array}$ & $\begin{array}{l}\text { Medical } \\
\text { treatment }\end{array}$ & $\begin{array}{c}\text { Residual } \\
\quad M I\end{array}$ & $\begin{array}{c}\text { Residual } \\
\text { mean } \\
\text { transmitral } \\
\text { gradient } \\
\text { (mm Hg) }\end{array}$ & $\begin{array}{l}\text { Follow-up } \\
(\text { mo })\end{array}$ \\
\hline 1 & No & - & I & No & 2 & 0 & 134.5 \\
\hline 2 & No & - & I & AVK & - & $\begin{array}{c}12 \\
\text { (SJM 19) }\end{array}$ & 95.5 \\
\hline 3 & No & - & I & AVK & - & $\begin{array}{c}6 \\
\text { (SJM 19) }\end{array}$ & 77 \\
\hline 4 & No & - & I & No & 1 & 0 & 85 \\
\hline 5 & - & - & - & - & - & - & Lost at $2 \mathrm{mo}$ \\
\hline 6 & No & - & I & No & 2 & 0 & 71 \\
\hline 7 & - & - & - & - & - & - & Lost at 3 mo \\
\hline 8 & No & - & - & - & 2 & 5 & 58 \\
\hline 9 & No & - & I & No & 1 & 0 & 16 \\
\hline 10 & $\begin{array}{c}\text { MVR } \\
\text { (Carbo 16) }\end{array}$ & $3 \mathrm{mo}$ & I & AVK & - & $\begin{array}{c}2 \\
\text { (Carbo 16) }\end{array}$ & 13 \\
\hline
\end{tabular}

MI, Mitral incompetence; $N Y H A$, New York Heart Association; $M V R$, mitral valve replacement; Carbo, CarboMedics valve; $A V K$, oral anticoagulant; SJM, St. Jude Medical valve.

MI were performed in one patient (patient 13). Papillary muscle splitting of a parachute mitral valve, resection of recurrent supravalvular mitral ring, and subaortic myectomy were done in patient 16. Finally, one patient (patient 18) underwent mitral valve replacement for residual MS 9 months after conservative treatment of a typical MS. This patient required a second valve replacement for valve thrombosis and died after unsuccessful thrombolytic therapy for valve rethrombosis. Autopsy confirmed the obstruction of the two prosthetic leaflets by organized thrombus. At latest follow-up, all patients were in NYHA class I except for one patient who has a moderate-to-severe residual MI and is in class II. Somatic development is normal in all patients. Mean native valve residual gradient is $3.2 \pm 1.6 \mathrm{~mm} \mathrm{Hg}$. Pulmonary artery pressures are normal or mildly elevated. One patient (patient 16) with Shone complex has recurrent subaortic stenosis and is scheduled for a Ross operation. Freedom from reoperation for congenital MS at 5 years is $54.8 \%$ (70\% CL $39.4 \%$ to $70.3 \%$ ) (see Fig. 3).

Reoperations. In total, five late reoperations were performed between 3 months and 8 years after the first procedure. Overall actuarial rate of freedom from reoperation including early reoperations is $58 \%$ (70\% CL $46.9 \%$ to $68.9 \%$ ) at 7 years (see Fig. 3 ). Although freedom from reoperation is lower in congenital MI than in congenital MS, there is wide overlapping of $70 \% \mathrm{CL}$.

Mortality. Overall actuarial survival is $94 \%(70 \%$ CL $88 \%$ to $100 \%$ ) at 7 years (Fig. 4).
Valve-related complications. Overall six patients have prosthetic mitral valves and receive warfarin. Early postoperative prosthetic valve thrombosis occurred in two cases, but no late thromboembolic or anticoagulant-related complications have been seen. One patient had septicemia without valve involvement. Mean prosthetic valve gradient is $6.2 \pm 3.7$ $\mathrm{mm} \mathrm{Hg}$ at latest follow-up.

\section{Discussion}

This study reports a 13-year experience with operations for congenital mitral valve anomalies in the first year of life in 20 patients, excluding atrioventricular canal defects, with no operative deaths and one late death. Mitral valve repair was initially performed in 19 of 20 patients and freedom from reoperation is $58 \%$ at 7 years. Limited information on congenital mitral valve disease excluding atrioventricular canal defects, operated on in infants, prompted us to review our results. Extreme heterogeneity of mitral valve structure, coexisting anomalies, patient ages, and era of treatment makes comparisons between series meaningless. Nevertheless, operative mortality in small children operated on for congenital mitral valve malformations has been high, particularly for those with MS or valve replacement. ${ }^{11,17-20}$ Although results have improved in recent years, surgical treatment is still a last resort. Indeed, valve replacement or even valve reconstruction does not claim to be a curative treatment restoring a normal valve physiology without sequelae. ${ }^{21}$ It is therefore justified, as in this series, to 


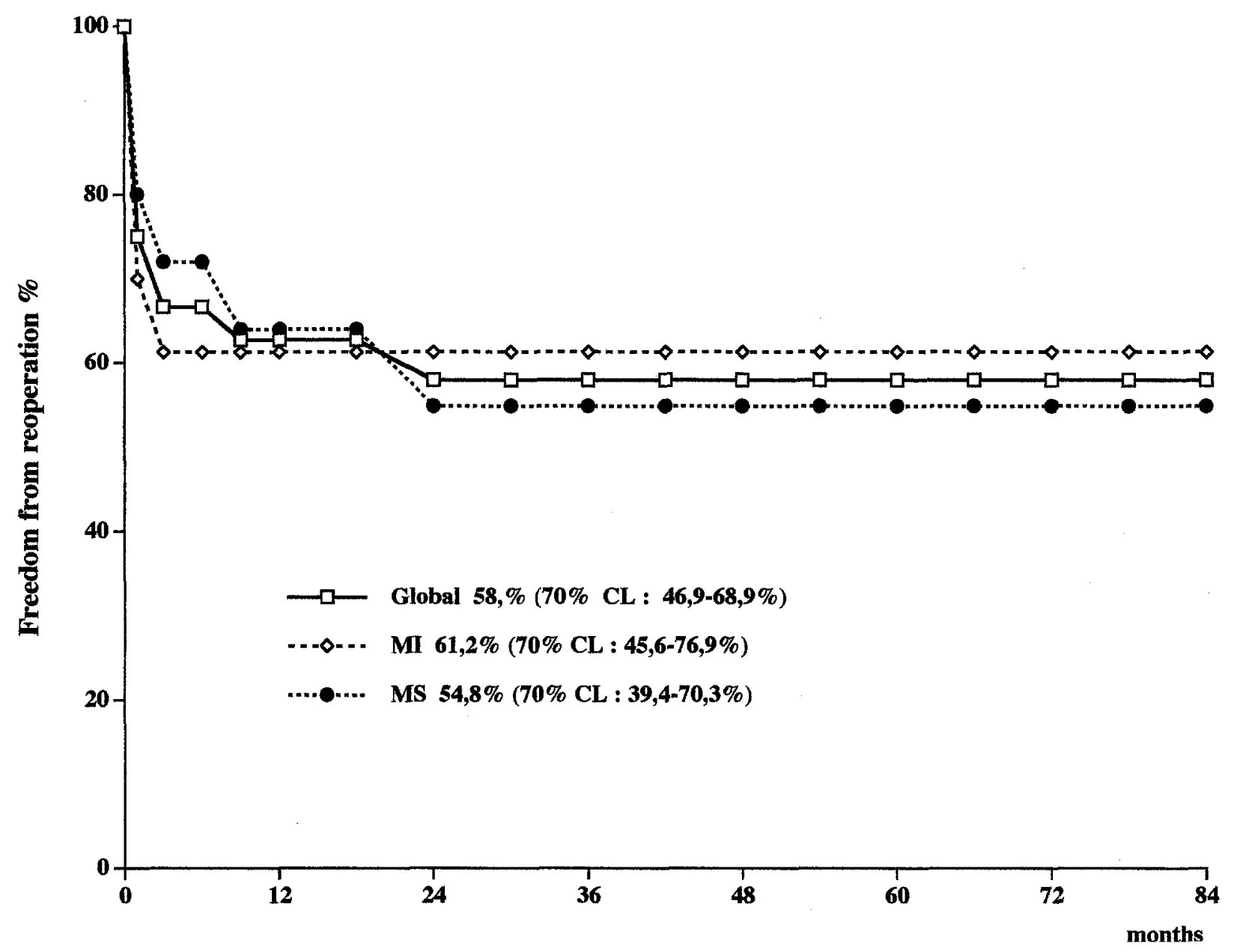

Fig. 3. Actuarial freedom from reoperation. Freedom from reoperation at 7 years is $58 \%$ (70\% CL $46.9 \%$ to $68.9 \%$ ) for the entire group, $61.2 \%$ (70\% CL $45.6 \%$ to $76.9 \%$ ) for patients with MI, and $54.8 \%$ ( $70 \%$ CL $39.4 \%$ to $70.3 \%$ ) for patients with MS.

operate only for severely symptomatic congenital mitral valve disease, the isolated cleft or supravalvular mitral ring being the rare exception to this rule. $^{22}$

Study population. In this series, associated lesions were present in $80 \%$ and $100 \%$ of patients with congenital MI and MS, respectively. These figures conform to reported clinical and anatomic series. $^{1-6}$ Severe MI after coarctation resection persisted in our patients, as it does in about a quarter of patients with this association of anomalies. ${ }^{23,24} \mathrm{Re}-$ stricted posterior leaflet motion was the most frequently encountered MI mechanism, resulting from leaflet hypoplasia, short chordae, or left ventricular dilatation. In three patients, isolated annular dilatation was the only detected anomaly, a similar incidence to that reported by Coles and associates. ${ }^{21}$
Although hypoplastic left heart syndrome was excluded from this study, at least two patients with MS had mitral/aortic anulus and left ventricular dimensions very close to values under which a biventricular repair is deemed unsafe, reflecting a spectrum of left-sided obstructive anomalies. ${ }^{25}$

Operation and early results. Reparative techniques for congenital $\mathrm{MI}$ in young children must rely on some type of segmental annuloplasty whether at the commissural or posterior leaflet level. ${ }^{14-16,26}$ Other reconstructive procedures at the subvalvular level, as described by Carpentier and associates, ${ }^{6}$ particularly for leaflet prolapse, may be helpful but were not used in this series. Three patients in this series (two of them operated on early in the series) had early failure of mitral valve repair and required valve replacement or a second repair because of 


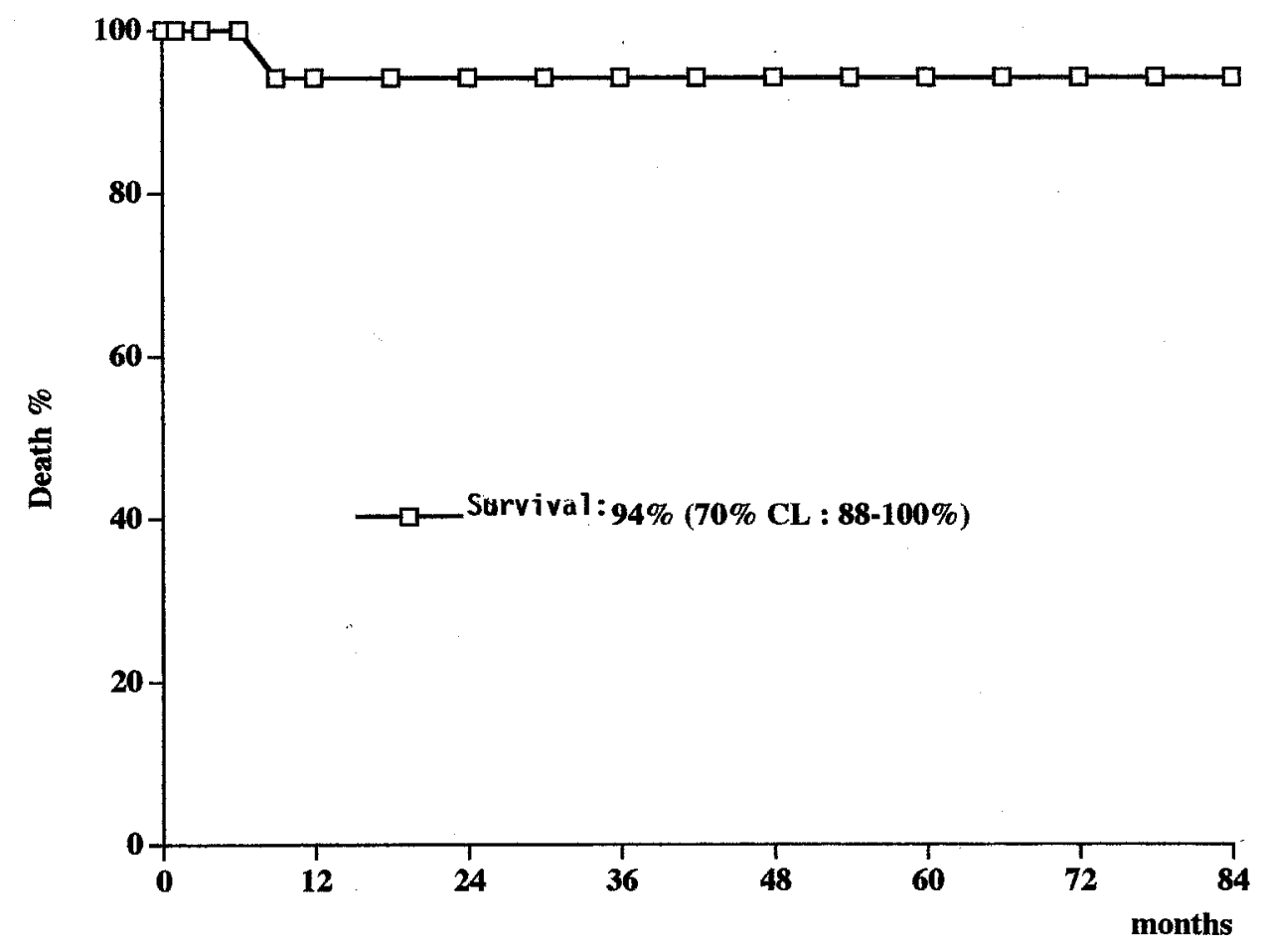

Fig. 4. Actuarial survival curve. Actuarial survival at 7 years is $94.1 \%$ ( $70 \%$ CL $88 \%$ to $100 \%$ ).

Table VII. Follow-up of patients with MS

\begin{tabular}{|c|c|c|c|c|c|c|c|}
\hline $\begin{array}{l}\text { Patient } \\
\text { No. }\end{array}$ & Late reoperations & $\begin{array}{l}\text { Interval } \\
\text { from first } \\
\text { operation }\end{array}$ & $\begin{array}{l}\text { NYHA } \\
\text { class }\end{array}$ & $\begin{array}{l}\text { Medical } \\
\text { treatment }\end{array}$ & Residual MI & $\begin{array}{c}\text { Residual } \\
\text { mean } \\
\text { transmitral } \\
\text { gradient } \\
\text { (mm Hg) }\end{array}$ & $\begin{array}{l}\text { Follow-up } \\
\text { (mo) }\end{array}$ \\
\hline 11 & No & - & I & No . & No & 6 & 127 \\
\hline 12 & Second MVR (SJM 23) & $8 \mathrm{yr}$ & I & AVK & - & 4 (SJM 23) & 120 \\
\hline 13 & AVR, MV annuloplasty & $9 \mathrm{yr}$ & I & AVK & 1 & 2 & 122 \\
\hline 14 & No & - & I & No & No & 3 & 80 \\
\hline 15 & No & - & I & AVK, diuretics & - & 7 (Björk 17) & 50 \\
\hline 16 & $\begin{array}{l}\text { MV repair, SAS resec- } \\
\text { tion }\end{array}$ & $2 \mathrm{yr}$ & I & No & $1-2$ & 2 & $\begin{array}{l}42, \mathrm{LV} / \mathrm{Ao} \\
90 \mathrm{~mm} \mathrm{Hg}\end{array}$ \\
\hline 17 & No & - & II & $\begin{array}{l}\text { Digoxin, } \\
\text { diuretics }\end{array}$ & $3-4$ & 4 & 38 \\
\hline 18 & MVR (Carbo 18) & 9 mo & - & - & 一 & - & Died at $6 \mathrm{mo}$ \\
\hline 19 & No & - & $\mathrm{I}$ & No & 2 & 2 & 15 \\
\hline 20 & No & - & - & AVK & No & 3 & 5 \\
\hline
\end{tabular}

$M S$, Mitral stenosis; $N Y H A$, New York Heart Association; $M I$, mitral incompetence; $M V R$, mitral valve replacement; $S J M$, St. Jude Medical valve; $A V R$, aortic valve replacement; $M V$, mitral valve; $S A S$, subaortic stenosis; $C a r b o$, CarboMedics valve; $A V K$, oral anticoagulant; $B j o ̈ r k$, Björk-Shiley valve; $L V / A o$, left ventricular/aortic gradient.

anterior leaflet prolapse and short chordae that could not be adequately corrected. Recognition of unsatisfactory results by intraoperative transesophageal echocardiography with infant-sized probes will certainly reduce the need for early reoperations after mitral valve repair. Surgical correction of MS in the first year of life remains a surgical challenge.
Difficulties arise from poor exposure of the subvalvular structures, annular hypoplasia, and left ventricular muscular crowding. Valvotomy and chordal fenestration, together with papillary muscle splitting and annular dilation, are undoubtfully useful palliative procedures that can result in some reduction in mitral valve gradient. ${ }^{1}$ Barbero-Marcial and associ- 
ates ${ }^{27}$ have recently reported a left ventricular apical approach for congenital. MS with no operative mortality and no significant residual MS. We have recently used an extended superior septal approach in a patient with parachute mitral valve that considerably improved mitral valve exposure. ${ }^{28}$ Instrumental annular dilation was used whenever a diminutive anulus obscured subvalvular structures or could not accommodate the smallest available prosthetic valve. In one patient a $17 \mathrm{~mm}$ Björk-Shiley valve had to be placed supraannularly. ${ }^{9}$ We have not used proposed alternatives to treat congenital MS, such as left atrial-left ventricular extracardiac conduit or mitral ring enlargement with double valve replacement. ${ }^{29-31}$ Some authors have recently used balloon angioplasty successfully in seven of nine patients with congenital MS, four of whom were less than 1 year old, but none had parachute mitral valve. ${ }^{32}$

Our repair-oriented policy has resulted in a $25 \%$ early reoperation rate but allowed for a good result in seven of ten cases of repaired congenital MI and five of nine cases of congenital MS without mortality. The objective, albeit imperfect, was to improve the patient's condition enough to avoid valve replacement altogether or at least to postpone it, thereby allowing for some annular growth. Indeed, although results of mitral valve replacement in early childhood have improved, a mortality rate of $30 \%$ was reported in recent studies. ${ }^{33,34}$ Bolling and associates $^{35}$ reported on a series of patients with Shone anomaly, with an average of 2.4 operations per patient and a $24 \%$ mortality. They found that severity of mitral valve obstruction correlated inversely with outcome. Noticeably, morphology greatly influences the difficulty of conservative treatment for congenital mitral valve disease during infancy. MI with leaflet restriction and MS caused by parachute or hammock-type mitral valves are particularly demanding. Ad integrum correction may be beyond reach in some infants with congenital mitral valve disease, but better results can be expected with increased experience and development of technical refinements.

Late results. After a mean follow-up of 5.5 years, good functional results were obtained in $95 \%$ of this series of cases. These children are free of symptoms and have a normal somatic development. Late follow-up of patients who underwent repair of congenital MI shows mild-to-moderate residual MI and regression of left ventricular dilatation. These results compare favorably with the reported $50 \%$ to $60 \%$ incidence of valvuloplasty failure after valve repair in older children. ${ }^{20}$ As could be expected, freedom from reoperation was less common (although not significantly so) in patients with congenital MS than in those with congenital MI; late reoperations were due to mitral dysfunction or associated left heart obstruction. Patients with congenital MS who underwent repair have trivial to mild residual MS and normalization of pulmonary pressures. Among the six patients who have prosthetic mitral valves in this series, five patients still face the risk of a second valve replacement, and one has undergone mitral valve replacement with a two-size upgrade.

The retrospective nature of this study, small number of patients, and wide spectrum of malformations preclude firm conclusions. However, some lessons may be drawn. Congenital malformations of the mitral valve in infancy are severe and difficult to treat, but operations can be performed with low mortality. Repair should be attempted and is feasible in the majority of cases of MI although less predictive in MS. The need for reoperations could be reduced with more experience but will remain a constant late hazard, particularly in patients with MS. Encouragingly, late functional results are good, most patients having a normal life.

\section{REFERENCES}

1. Collins-Nakai RL, Rosenthal A, Castaneda A, Bernard WF, Nadas A. Congenital mitral stenosis: a review of 20 years' experience. Circulation 1977;56: 1039-47.

2. Davachi F, Moller JH, Edwards JE. Diseases of the mitral valve in infancy. Circulation 1971;48:565-79.

3. Ruckman RN, Van Praagh R. Anatomic types of congenital mitral stenosis: report of 49 autopsy cases with consideration of diagnosis and surgical implications. Am J Cardiol 1978;42:592-601.

4. Eastope RN, Tawes RL, Bonham-Carter RE, Aberdeen $\mathrm{E}$, Waterston DJ. Congenital mitral valve disease associated with coarctation of the aorta. Am Heart J 1969;77:743-54.

5. Rosenquist GC. Congenital mitral valve disease associated with coarctation of the aorta: a spectrum that includes parachute deformity of the mitral valve. Circulation 1974;49:985-93.

6. Carpentier A, Branchini B, Cour JC, et al. Congenital malformations of the mitral valve in children: pathology and surgical treatment. J ThoraC CARDIOVASC SURG 1976;72;854-66.

7. Berghuis J, Kirklin JW, Edwards JE, Titus JL. The surgical anatomy of isolated congenital mitral insufficiency. J THORAC CARdiovasc SuRg 1964;47:791-8.

8. Shone JD, Sellers RD, Anderson RC, Adams P, 
Lillehei CW, Edwards JE. The developmental complex of "parachute mitral valve," supravalvular ring of left atrium, subaortic stenosis, and coarctation of aorta. Am J Cardiol 1963;11:714-25.

9. Kadoba K, Jonas RA, Mayer JE, Castaneda AR. Mitral valve replacement in the first year of life. J ThOrac Cardiovasc Surg 1990;100:762-8.

10. Van der Horst RL, Hastreiter AR. Congenital mitral stenosis. Am J Cardiol 1967;20:773-83.

11. Kirklin JW, Barratt-Boyes B. Congenital mitral valve disease. In: Cardiac surgery, 2nd ed. New York: Churchill Livingstone, 1993:1343-59.

12. Stellin G, Bortolotti U, Mazzucco A, et al. Repair of congenitally malformed mitral valve in children. J ThORAC CARDIOVASC SuRg 1988;95:480-5.

13. Goldberg SJ, Allen HD, Sahn OJ. Pediatric and adolescent echocardiography: a handbook. 2nd ed. Chicago: Year Book, 1980.

14. Wooler GH, Nixon PGF, Grimshaw VA, Watson DA. Experiences with the repair of the mitral valve in mitral incompetence. Thorax 1962;17:49-57.

15. Kay JH, Egerton WS. The repair of mitral insufficiency associated with ruptured chordae tendineae. Ann Surg 1965;157:315-25.

16. Reed GE, Tice DA, Clauss RH. Asymmetric exaggerated mitral annuloplasty: repair of mitral insufficiency with hemodynamic predictability. J THORAC CARDIOVASC SURG 1965;49:752-61.

17. Khalil KG, Shapiro I, Kilman JW. Congenital mitral stenosis. J THORAC CARdIOvasC SURG 1975;70:40-5.

18. Almeida RS, Elliot MJ, Robinson PJ, et al. Surgery for congenital abnormalities of the mitral valve at the Hospital for Sick Children, London from 1969-1983. J Cardiovasc Surg 1988;29:95-9.

19. Sethia B, Sullivan ID, Elliot MJ, de Leval M, Stark J. Congenital left ventricular inflow obstruction: Is the outcome related to the site of the obstruction? Eur J Cardiothorac Surg 1988;2:312-7.

20. Okita Y, Miki S, Kusuhara K, et al. Early and late results of reconstructive operation for congenital mitral regurgitation in pediatric age group. J THORAC Cardiovasc SuRg 1988;96:294-8.

21. Coles JG, Williams WG, Watanabe T, et al. Surgical experience with reparative techniques in patients with congenital mitral valvular anomalies. Circulation 1987;76(Suppl):III117-22.

22. Sullivan ID, Robinson PJ, de Leval M, Graham TP. Membranous supravalvular mitral stenosis: a treatable form of congenital heart disease. J Am Coll Cardiol 1986;8:159-64.

23. Freed MD, Keane JF, Van Praagh R, Castaneda AR, Bernhard WF, Nadas AS. Coarctation of the aorta with congenital mitral regurgitation. Circulation 1974; 49:1175-84.

24. Terzaki AK, Leachman RD, Khalil AM, Hallman GL, Cooley DA. Congenital mitral incompetence and coarctation of aorta: report of two cases treated surgically. Thorax 1972;27:729-37.

25. Leung MR, McKay R, Smith A, Anderson RH, Arnold R. Critical aortic stenosis in early infancy. J Thorac Cardiovasc Surg 1991;101:526-35.

26. de Vega NG. La anuloplastia selectiva, regulable y permanente. Rev Esp Cardiol 1972;25:555-66.

27. Barbero-Marcial M, Riso A, de Albuquerque AT, Atik E, Jatene A. Left ventricular apical approach for the surgical treatment of congenital mitral stenosis. J Thorac Cardiovasc Surg 1993;106:105-10.

28. Guiraudon GM, Ofiesh JG, Kaushik R. Extended vertical transatrial approach to the mitral valve. Ann Thorac Surg 1991;52:1058-62.

29. Laks H, Hellebrand WE, Kleinman C, Tainer NS. Left atrial-left ventricular conduit for relief of congenital mitral stenosis in infancy. J THORAC CARDIOVASC SURG 1980;80:782-7.

30. Amodeo A, Di Donato R, Corno A, et al. Systemic atrioventricular conduit for extracardiac bypass of hypoplastic systemic atrioventricular valve. Eur J Cardiothorac Surg 1990;4:601-4.

31. Rastan H, Atai M, Hadi H, Yazdanya A. Enlargement of mitral valvular ring: new technique for double valve replacement in children or adults with small mitral anulus. J Thorac CARDIOvaSC SURG 1981;81:106-11.

32. Spevak PJ, Bass JL, Ben-Sachar G, et al. Balloon angioplasty for congenital mitral stenosis. Am J Cardiol 1990;66:472-6.

33. Adatia I, Jonas R, Moore P, Keane JF. Supraannular mitral valve replacement in early childhood. J Am Coll Cardiol 1994;306A.

34. Zweng TN, Bluet MK, Mosca R, Callow LB, Bove EL. Mitral valve replacement in the first 5 years of life. Ann Thorac Surg 1989;47:720-4.

35. Bolling SF, Iannettoni MD, Dick M, Rosenthal A, Bove EL. Shone's anomaly: operative results and late outcome. Ann Thorac Surg 1990;49:887-93.

\section{Discussion}

Dr. Lari A. Attai (Bronx, N.Y.). For historic reasons, I would like to present the case history of a 31-year survivor, a patient with congenital MS, who has undergone three prosthetic valve replacements thus far.

On June 16, 1963, Dr. George Robinson replaced the mitral valve of a 10 -month-old infant who was born with congenital MS. He used the then-available dog model of the Starr-Edwards aortic valve prosthesis in the mitral position. The procedure was done through a left thoracotomy in an empty, beating heart, which was the approach of choice at that time. The infant survived the operation and required a second procedure 2 years later at 3 years of age.

The first explanted prosthesis had ingrowth of endocardial tissue on the atrial side under the apex of the cage. The cross-sectional surface of the valve was $0.8 \mathrm{~cm}^{2}$. The second valve, inserted in 1965, was a similar but larger prosthesis. Its cross-sectional surface area was $1.5 \mathrm{~cm}^{2}$. 
The patient did very well and was married at the age of 26 years. Incident to her honeymoon in Hawaii and to marital activities, she became severely symptomatic again, with shortness of breath on exertion, fatigue, and near syncopal episodes. Recatheterization showed supersystemic pulmonary hypertension (a pressure of about 140 $\mathrm{mm} \mathrm{Hg}$ versus an aortic pressure of $100 \mathrm{~mm} \mathrm{Hg}$ ) and significantly reduced cardiac index.

I reoperated on her in 1985 , shortly after her return from her honeymoon. This operation was done through a right thoracotomy and again-that was in 1965-in an empty, warm, beating heart. The third operation was done through a median sternotomy and was done through our current approach, which is with the aorta crossclamped and cardioplegic arrest of the heart. She survived the operation and currently is alive and well, enjoying full employment and her married life.

I present this case for historic reasons. This may be the longest survival time after valve replacement in a patient with congenital MS. This case represents the evolution of the surgical approach to mitral valve replacement in general and the remarkable durability of the Starr-Edwards valve, which lasted for 24 years without any structural changes in the valve at all.

Dr. Roland Hetzer (Berlin, Germany). We have been following an almost identical concept during the past 6 years. Since starting our pediatric program in Berlin 6 years ago, we have operated on 275 atrioventricular valves in the pediatric group. Only eight mitral valve replacements were included in the whole group. Invariably, mitral valve replacement was done after two or three previous reconstructions.

This group included 58 patients with nonatrioventricular canal type mitral defects. Nine infants were operated on at the age of 2 weeks to 1 year. The valve anomalies included annular dilatation, Shone complex, parachute valve, and abnormal clefts. Various types of repair were attempted: suture techniques such as the Kay-Wooler repair or the Paneth repair along the entire posterior anulus, papillary muscle splitting, and fenestration. All children survived. Four reoperations have been done since then, again with mitral repair, because we try to repair the mitral valve at all costs.

I would like to ask you three questions: What degree of MI would you accept before reoperating on an infant or a small child? What type and what size of prosthesis have you used in these children? Which type of abnormality would you consider as a primary indication for mitral valve replacement in this age group?

Dr. Sousa Uva. Thank you for your comments and questions. Regarding the criteria for reoperation, one should consider the degree of MI and the severity of symptoms. The indication for reoperation is the association of severe residual MI and persisting debilitating symptoms. The same applies for MS.

Regarding the size of prosthesis, we have inserted two $17 \mathrm{~mm}$ Björk-Shiley valves, one of them supraannularly. The remaining are bileaflet valves (St. Jude Medical and CarboMedics) ranging between $16 \mathrm{~mm}$ and $19 \mathrm{~mm}$. One patient has had a second valve replacement, and the original $19 \mathrm{~mm}$ St. Jude Medical valve was replaced by a $23 \mathrm{~mm}$ St. Jude Medical valve.
The wide morphologic spectrum of congenitally malformed mitral valves makes it difficult to codify pathologic types. It is important to carefully analyze all components of the mitral valve before deciding whether to repair or to replace the valve. Hammock mitral valve and some parachute mitral valves are beyond the possibilities of repair, and valve replacement may be unavoidable. Regurgitant mitral valves with restricted leaflet motion and leaflet hypoplasia can sometimes be a technical challenge, particularly when there is direct leaflet-papillary muscle attachment with very short or absent chordae. Intraoperative transesophageal echocardiography may well prove to be an important adjunct for the management of these infants undergoing mitral valve surgery. Intraoperative evaluation of valve repair will probably increase the indications for conservative treatment and reduce the incidence of early reoperations.

A perfect repair is almost always impossible to achieve in these patients. The objective is to improve the patient's clinical condition. This improvement is frequently synonymous with a normal life for a long time and, if valve replacement is ultimately required, annular growth has allowed for implantation of a larger mitral prosthesis.

Dr. Edward L. Bove (Ann Arbor, Mich.). The most challenging group for most of us are the infants with isolated congenital MS. If I understood your data correctly, five of your patients with isolated MS had good results. Presumably in one or more of those the primary abnormality was a supravalvular mitral ring. Did these patients have any other unifying morphologic characteristics?

Dr. Sousa Uva. Ten patients had predominant MS. Among them there were four patients who had a membranous supravalvular ring, but in only one case there was an isolated supravalvular ring. In the other cases a membranous ring was associated with a parachute mitral valve or a Hammock mitral valve. Thus there was only one in which the procedure consisted of a pure resection of the membranous ring.

Dr. Bove. How many of those patients had good results with just a commissurotomy?

Dr. Sousa Uva. The only patient with isolated mitral ring is doing fine.

Dr. Bove. How many of those patients without supravalvular mitral rings is what I was asking.

Dr. Sousa Uva. Only one patient had a simple commissurotomy.

Dr. William G. Williams (Toronto, Ontario, Canada). The congenitally stenotic mitral valve is a problem because the chordae are not merely short, they are nonexistent. The papillary muscles tend to fuse with the leaflets. Have you any technical tricks to deal with that situation, or do you simply compromise and open the leaflets as much as possible from above?

Dr. Sousa Uva. One of the important issues is to determine the best route by which to approach the mitral valve: through the interatrial groove, the interatrial septum, or, as reported recently by a Brazilian group, through a left ventricular approach. Most of the time we have approached the mitral valve through the interatrial groove and occasionally through the interatrial septum. Recently we have used an extended superior septal approach, which 
has considerably improved the exposure. Good mitral valve exposure is crucial for an appropriate anatomic analysis and for adequate access to the subvalvular level.

About the surgical tricks, we start by doing commissurotomy and annular dilation to improve the exposure of the subvalvular apparatus. Then we perform chordal fenestration and papillary muscular splitting, keeping in mind that we cannot be too ambitious because of the risk of creating severe mitral regurgitation. The idea is to improve the gradient enough for the patient's condition to improve without creating iatrogenic mitral regurgitation.
I would like to stress that balloon valvuloplasty represents another option for patients with MS. The group from Boston Children's Hospital has reported this kind of treatment in some patients with MS; however, none of those patients had parachute mitral valve, which is considered a contraindication to balloon valvuloplasty. Some patients may be amenable to percutaneous intervention, but the indications and results of balloon valvuloplasty are not yet clearly established.

\section{1-800-55-MOSBY}

This number links you to the full text of literally every article ever published in Mosby Journals. MOSBY Document Express ${ }^{\mathrm{TM}}$, a rapid response information retrieval service, provides quick turnaround, 24-hour availability, and speedy delivery methods. For inquiries and pricing information, call our toll-free, 24-hour order line: 1-800-55-MOSBY; outside the US: 415-259-5046; fax: 415-259-4019; E-mail: mosbyexp @class.org.

MOSBY Document Express ${ }^{\mathrm{TM}}$ is offered in cooperation with Dynamic Information Corp. 